\title{
The Competency and Demand of High Technology Enterprise
}

\author{
Xiaozhe Yun \\ Beijing Information Science \& Technology University \\ Beijing 100192, China \\ E-mail: xzy315@126.com
}

\begin{abstract}
The acquisition and management of the human resources is the key to the success in high-tech enterprises. Since the enterprise management such as the total quality management, organization flexibility and flat, process reengineering, streamlining of the organization and organizational integration is rising and developing, high-tech enterprises have to concentrate on recognizing and developing the competency of the human resources. Updating the competency of the human resources has been requested by the characters of high-tech enterprises and the natures of human resources. The new competency of the human resources should include initiative active, team communication and cooperation, logical reasoning and analysis and achievement-oriented.
\end{abstract}

Keywords: High-tech enterprise, Human resources, Competency, Demand

\section{High-tech enterprises' traits}

As an important field of economic activities, this kind of enterprises is the focus of many science studies. Compared with traditional companies, high-tech enterprises' traits act differently when based on different study subjects. From the angle of human resources, they will appear these traits:

1) The main strategy of enterprises is human capitals; the management of HR is the central point of enterprises' management.

2) The sensible elements of enterprise's benefits does not only include their employee's personal competences, but more also the enterprise's whole HR's quality and quantity.

3) The working contents of an employee complicate, their techniques specialized and the position of his abstracts. The responsibilities of staff are not a person-a position anymore, but a person fits more positions and a position can have more employees.

4) The management of people changes from controlling-oriented to encouragement-oriented. The guiding index of comments on an employee is his working benefits, but not his working production rate.

5) The competition among enterprises mainly focuses on HC's competition.

\section{High-tech enterprises' human capitals are different from human resources}

According to the point of economist Weijie, the human capitals in enterprises are mainly these two kinds of people: The first kind of people are called technical innovator, the other kind are called professional manager. It is different from human resources which includes all the people in enterprises. In high-tech enterprises, the working traits of human capitals are different from those ordinary ones, they deal with knowledge-intensive issues and emphasize on self-management. Generally speaking, high-tech enterprises' human capitals mainly mean those who use professional techniques and knowledge to deal with company's operation and management issues. Their working is specialized and complex. Therefore, human capitals' management is different from traditional human resources" management.

\section{The ability and competency of human capital}

\subsection{The traditional of human capital}

Ability is usually referred to one's skill or competence. For example, we always think that one who can drive or write computer program is the competent. Strictly speaking, it means the level one can reach to be measured objectively; as a result, we can make up a set of normative standards to measure one's ability. Such kind of standards can be used broadly in the process of the management of human resource, such as to measure one's capacity, to employ, train and select somebody. Traditional enterprises have applied the technology of work analysis to determine the necessary skill and knowledge for certain job, and accordingly to employ workers, assess performance and train workers. Generally speaking, the management of human resource in traditional enterprises is ability-based.

However, with the development of market competition, making the organization flat, the direction of the team and the 
ability of innovation become the key advantage in the competition. In the High-tech Enterprises, workers have become knowledge workers who must work without work specifications. In order to keep high-speed on the reaction to the environment, enterprises must grant more autonomy and elasticity to their workers and work has no longer been divided into several jobs, for which everyone has clear range. Traditional worker management model of "A carrot of a pit" has been hardly adapt to the volatile and complex environment and cannot meet the need of innovation for the High-tech Enterprises. In this condition, the Competency-based human resource management came into being.

\subsection{The concept of competency}

It was first proposed by McClelland, a professor at Harvard University in 1973. He doubted the phenomenon of widespread use in intelligence tests to select students in higher education, and said that more emphasis should be put on the competency which practically influences the performance of study rather than IQ. With the proposing of competency, different interpretations and definitions are given by many scholars. The simplest definition of competency is as follows: the ability and willingness to carry out its mandate, or the ability to use knowledge and skills to carry out the work. But Hayes, president of the American Management Association, and McBer consulting company insisted that competency went beyond the simple level having the ability to perform, was the integration of knowledge, character, motivation, self-concept (or social roles), and inter-personal skills, which brought out an outstanding performance.

We may sum up the concept of competency as the required knowledge, skills, ability, quality and attitude by a person in order to achieve superior performance, not only includes the current personal knowledge, experience and skills, but also includes the potential ability in its possible future and capacity development through learning, covered by the explicit of act skills to the implicit values, feelings or attitudes. These competency items are closely related to individual job performance, and most can be improved or changed through learning and training. The recognition and development of competency become a major topic in the realm of HR management in recent years, and the main reason is that competency management of human capital may:

\subsubsection{Improve performance of staff \& enterprise}

In line with the corporate strategy and culture business through the recognition and development of the competency required by work (including knowledge, technology, attitude or self-cultivation, etc), encourage employees to work in more efficient way to complete its work resulting in better performance, and further efficiently use of the whole enterprise of human resources contributed to the achievement of business performance.

\subsubsection{Meet the needs of long-term development of corporate HR}

In the future times of knowledge-based work competition, the quality of corporate human resources must be constantly improved. Only by updating the knowledge, technology and ability can we form competitive capital difficult for competitors to imitate. The recognition and development of human capital competency is just to meet these needs, to get respect knowledge, technology and ability, to get systemic and long-term development.

\section{Competency required of human resources in high-tech enterprises}

The acquisition and management of the human resources is the key to the success in high-tech enterprises. Since the enterprise management including the total quality management, organization flexibility and flat, process reengineering, streamlining of the organization and organizational integration is rising and developing, high-tech enterprise has to concentrate on recognizing and developing the competency of the human resources. Updating the competency of the human resources has been requested by the characters of high-tech enterprises and the natures of human resources. The new competency of the human resources should include initiative active, team communication and cooperation, logical reasoning and analysis and achievement-oriented.

On understanding something or doing some work till now. Ability is the product of postnatal learning (formal and informal), in the condition of inborn circumstances. In other words, people traditionally think that ability means the knowledge, skill and attitude one holds.

Under such explanation, firstly, ability is one kind of input. Secondly, a person who accords to the qualification is able to effectively accomplish the mission. Third, such kind of knowledge and skill can

\subsection{Initiatively active}

On the one hand, human resources' work can not be invariable as their main responsibility in high-tech enterprises is innovative, increasing the difficulty in control and management of them; on the other hand, addition to the institutional building such as organization structure, business process, the key requirement in high-tech enterprises is the initiative participation and contribution of human resources, as the high-tech enterprises should respond elastically and rapidly to the complex and changeable business environment. In other words, besides necessary professional knowledge and technology, excellent human resources should put theories into practice initiatively, and unceasingly enhance and progress this initiative as well. Therefore, initiative attitude to its work is absolutely necessary for one to be an excellent talent of enterprises. 


\subsection{Team communication and cooperation}

In the high-tech enterprise, with the increase of the technique complexity and the task difficulty, the enterprise no longer requires the employers of working alone in a heroic way but of their teamwork attitude and habit. The enterprise no longer requires the human resources of the specialization and the ever growing technique. As with the increase of task complexity, one person isn't possible to complete a whole project. Because of the more detailed and deeper in specialization theory, the persons with more specialized knowledge and techniques are becoming fewer and fewer. So the completion of a project needs the melting of different subjects and the communication and cooperation. Only in this way can create and cooperate the competitive products. In the enterprise, not only the colleagues in the same department need cooperate but also those in different departments also need communication and cooperation. Therefore, to be an excellent high-tech human resource, it's necessary to equip with cooperation.

\section{3 achievement guide}

Owing to the rapid changing of the industry environment, the high-tech enterprise needs to use the goal achievement rate to evaluate the human resource achievement. Willing to achieve the goal of the company is also the basic requirement which the human resource in the high-tech enterprise should equip with. Human resources should take pride in the challenging goal, be delighted to achieve it and have a strong motivation. Therefore, the quality of the achievement guide is the requirement of predicting the human resources achievement.

\subsection{Logical reasoning and analysis}

Cut-throat competition environment and rapid development step requires high technology industry to solve business problems in a short time, especially company losses due to controlling problems. Hence the ability of analyzing reasons and judge the key point of problems is very important. Therefore, excellent person could find and conclude many abnormal phenomenons and find potential problems before they happened in order to avoid troubles. That is to say, they must possess excellent control ability. It requires HR capital have favorable logical reasoning ability and analysis competency.

There are four basic competencies for HR capital in high-tech industry: ambitions, teamwork and cooperation, logical consequence and analyzing, achievement target. In order to get excellent HR capital, company always uses training and employment methods. That is to say, if the company thinks some of the four basic competencies could strengthen through education, it could be classified as the training item; but if managers consider it couldn't be improved through education, it should be attributed to the employment index according to its degree.

\section{References}

John, W. Newstrom, \& Keith, Davis. (1998). Organizational Behavior, pp. 461-492.

Lawrence, S. Kleiman. (1998). Human Resource Management, pp. 322-328.

Li, Baoshan. (2007). High-tech Industries Require High-tech Management Technique. Journal of Henan Institute of Finance and Economics, 6:26-27. 